\title{
Peran Perempuan dalam Ibadah: Dialektika Politik dan Teologi Tubuh
}

Agus Surya

Institut Agama Kristen Negeri Palangka Raya, Kalimantan Tengah

agus080311@gmail.com

\begin{abstract}
This paper presents an analysis of the text of 1 Timothy 2: 8-12 in relation to the role of women in worship. Where will be studied in the dialectic of body politics and body theology. The dialectic referred to is related to limiting the role of women as leaders in worship. The study in this paper uses a qualitative descriptive method. Data were collected using literature study techniques. The results of the study illustrate that the text of 1 Timothy 2: 8-12 presents an unrestricted role for women in ministry in the Ephesian church. The assumption that the role of women is limited in their service in the congregation actually comes from feminism. Timothy's text study actually wants to emphasize that the role of women in church service is not limited and has the same obligations as men, and has the same value before God.
\end{abstract}

Keywords: politic; theology; women; worship

Abstrak: Tulisan ini menyajikan analisis teks 1 Timotius 2:8-12 dalam kaitannya dengan peran perempuan dalam ibadah. Dimana akan dikaji dalam dialektika politik tubuh dan teologi tubuh. Dialektika yang dimaksud berkaitan dengan pembatasan peran perempuan sebagai pemimpin dalam ibadah. Kajian dalam tulisan ini menggunakan metode deskriptif kualitatif. Data dikumpulkan dengan teknik studi pustaka. Hasil penelitian memberikan gambaran bahwa teks1 Timotius 2:8-12 menyajikan peran perempuan yang tidak dibatasi dalam pelayanan di jemaat Efesus. Anggapan peran perempuan dibatasi pelayanannya di jemaat justru datang dari kaum feminisme. Kajian teks Timotius sejatinya ingin menekankan bahwa peran perempuan dalam pelayanan jemaat tidak dibatasi dan memiliki kewajiban yang sama dengan laki-laki, serta memiliki nilai yang sama di hadapan Allah.

Kata kunci: ibadah; perempuan; politik; teologi

\section{PENDAHULUAN}

Tulisan ini membahas kajian teologi tentang peran perempuan dalam ibadah. Teologi merupakan ilmu ketuhanan, atau ilmu tentang Tuhan, secara implisit, dapat dikatakan bahwa objek kajiannya adalah Tuhan. Seperti ilmu-ilmu lain, misalkan, antropologi, objek kajiannya adalah manusia, geologi, objek kajiannya adalah bumi. Berbeda dari antropologi dan geologi, objek kajian teologi, bukanlah Allah, sebab Allah tidak mungkin untuk diobjekkan, jika Allah di objekkan, maka hasilnya selalu negatif, sebab jika Allah diobjekkan, dapat diibaratkan seperti kita hendak menggendong diri kita sendiri. Objek teologi, bukanlah Allah yang nun jauh disana, melainkan Allah yang dapatdijumpai dalam keseharian hidup orang percaya. ${ }^{1}$

\footnotetext{
${ }^{1}$ A. Setyawan, Teologi Seksual (Yogyakarta: Kanisius, 2014), 17-18.
} 
Teologi merupakan sebuah refleksi orang percaya atas seluruh keberadaan hidupnya ditengah-tengah dunia ini. Dasar dari kajian teologi melibatkan kepercayaan terhadap Allah yang ia percayai. Allah (Alkitab) menjadi fitur "kamera" atas setiap pengalaman dan keberadaan hidupnya. Karena itu, teologi menjadi penting dalam rangka untuk memuliakan Allah melalui hidup dan keberadaan setiap orang percaya. ${ }^{2}$ Para feminis Kristen, seperti perempuan sekuler juga, menyadari bahwa tubuh perempuan telah dibebani dengan beban berat di bawah teologi patriarkal. Dari saat perempuan diminta untuk percaya bahwa Hawa adalah tulang rusuk yang dikeluarkan dari Adam. Perempuan memahami bahwa teologi didasarkan pada tubuh, perempuan berada pada posisi yang tidak menguntungkan. Ini akan menjadi peran perempuan dalam agama dan teologi, bertindak sebagai 'orang lain', orang luar, bagi pria, Tuhan dan gereja. Laki-laki adalah norma penciptaan dan perempuan tidak pernah cukup maju; semua yang unik tentang dirinya dianggap cacat dan mencurigakan. Dia diajari untuk tidak mempercayai dirinya sendiri, terutama pengetahuan yang dia peroleh melalui keberaniannya, memahami tubuhnya. Pria akan menentukan siapa perempuan itu, ia diberikan sanksi ilahi untuk menamainya (Kej. 2.23-24) dan ia akan menentukan bagaimana perempuan itu melihat dirinya sendiri dan dunia. ${ }^{3}$

Demikian pula dengan Esther Fuchs, menyatakan bahwa Alkitab lahir dan dibentuk dalam konteks kebudayaan patriarkal yang kuat sehingga bersifat androsentris atau berpusat pada laki-laki. ${ }^{4}$ Akibatnya, penggambaran-penggambaran tentang kaum perempuan dalam Kitab Suci selalu ditampilkan dalam hubungannya dengan tokoh-tokoh lakilaki, dan berasal dari perspektif kaum laki-laki sehingga kaum perempuan selalu menjadi karakter sekunder dalam teks-teks yang ada. Di sinilah, status perempuan dalam Alkitab adalah sebagai yang terpinggirkan sehingga Alkitab perlu dilihat sebagai kumpulan tulisan yang turut serta melanggengkan politik dominasi kaum laki-laki baik pada masa kemunculannya dalam konteks masyarakat Israel kuno maupun dalam konteks kekinian. ${ }^{5}$

Pergumulan terkait peran perempuan dalam ibadah masih terjadi hingga kini. Hal ini terlihat dari hasil penelitian yang diungkapkan oleh Yuli Nur Rafika. Hasil penelitiannya di jemaat HKBP Yogyakarta memenunjukkan bahwa kepemimpinan lebih berhak dipegang oleh laki-laki. Perempuan dianggap lemah dan hanya pantas untuk memegang peran domestik saja dari pada memegang otoritas sebagai pemimpin. ${ }^{6} \mathrm{Hal}$ ini disebabkan karena budaya patriarki yang diikuti oleh masyarakat Batak. Selain itu, gereja sudah terbiasa dengan tradisi bahwa laki-laki sebagai pemimpin dan tidak mengenal tradisi lain. Pengaruh kebudayaan atas gereja sangat kuat, peranan perempuan dan laki-laki berakar dalam kebudayaan serta adat dan akar ini sangat dalam. Namun seiring berjalannya waktu, gereja HKBP mulai terbuka dan menerima keberadaan perempuan dan memberikan hak yang sama dengan laki-laki meskipun masih dibatasi. Persoalan ini juga diungkapkan Frans

\footnotetext{
${ }^{2}$ Ibid., 23-24.

${ }^{3}$ Lisa Isherwood \& Elizabeth Stuart, Introductions in Feminist Theology: Introducing Body Theology (England: Sheffield Academic Press, 1998), 15-16.

${ }^{4}$ Esther Fuchs, Sexual Politics in the Biblical Narrative: Reading the Hebrew Bible as a Woman (London: Sheffield Academic Press, 2000), 11.

${ }^{5}$ Ibid. 11-12.

${ }^{6}$ Yuli Nur Rafika, Kepemimpinan Perempuan Dalam Gereja Menurut Gereja Huria Kristen Batak Protestan (HKBP) Kotabaru Yogyakarta (Yogyakarta: UIN SUNAN KALIJAGA, 2018).
} 
Geras. Hasil penelitiannya mengungkapkan bahwa tidak semua gereja atau jemaat yang ada di gereja GKII Daerah III Nabire, menolak perempuan untuk terlibat dalam pelayanan di gereja, hanya ada di gereja tertentu saja yang menolak perempuan untuk melayani di gereja. ${ }^{7}$ Lebih lanjut, Shintia dkk menegaskan, nyata bahwa masih terdapat masalah dalam peran perempuan di kalangan organisasi Kristen dan dalam hal ini adalah gereja. ${ }^{8}$ Ketiga pandangan dan hasil penelitian ini menegaskan bahwa pada masa kini dalam kehidupan bergereja, peran perempuan dalam pelayanan di gereja masih menyisahkan persoalan.

Berdasarkan persoalan di atas, penulis akan memberikan analisis dan mengkaji lebih lanjut terkait peran perempuan dalam pelayanan di gereja. Problematika peran perempuan ini disorot oleh kaum feminis yang mengganggap seolah-olah Rasul Paulus tidak mengakui adanya kesetaraan gender antara laki-laki dan perempuan dalam pelayanan di jemaat. Adapun rumusan masalah dalam tulisan ini adalah bagaimana teks1 Timotius 2:8-12 memaknai peran perempuan dalam pelayanan jemaat. Untuk memperolah hasil analisis terkait persoalan tersebut, penulis akan mengkaji teks 1 Timotius 2:8-12, sebagai dasar untuk menyelusuri peran perempuan dalam gereja dan merefleksikannya dalam pelayanan masa kini.

\section{METODE PENELITIAN}

Tulisan ini menggunakan metode penelitian deskriptif kualitatif. Analisis data kulitatif dapat dilakukan dengan menggunakan beberapa model, seperti model kesamaan (similarities) dan perbedaan (differences). Melalui model kesamaan, analisa dilakukan dengan membuat gambaran-gambaran rinci mengenai data sosial yang ditemukan di lapangan kemudian dibuat beberapa kesimpulan sementara. ${ }^{9}$ Pendekatan literatur menjadi bagian penting dalam mengumpulkan data terkait topik peran perempuan dalam gereja. Selain itu, penulis belakukan kajian terdapat teks 1 Timotius 2:8-12. Hasil analisis terhadap teks tersebut akan dipadukan dengan kajian leteratur lainnya lalu merefleksikannya dengan peran perempuan dalam pelayanan di gereja masa kini menjadi dasar untuk menjawab persoalan dan menyimpulkan hasil penelitian.

\section{PEMBAHASAN}

Pembahasan ini bertolak dari pertanyaan berikut: Bagaimana dengan pandangan Paulus terhadap perempuan? Apakah Paulus anti perempuan, seperti yang ditunjukkan para lakilaki di zamannya? Dalam beberapa tulisannya (Gal. 3:28; 1 Kor. 7:3; dan Ef. 5:25-33) Paulus secara eksplisit membela kaum perempuan. Banyak perempuan memiliki kedudukan kepemimpinan yang menonjol (Febe, Lydia, Euodia, Sintikhe, Priskila, Yunias), ditunjuk sebagai diaken (Rm. 16:1), teman sekerja (Rm. 16:3), kawan sekerja dalam Injil

${ }^{7}$ Frans Geras, "Peranan Perempuan Dalam Mengembangkan Pelayanan Di Gereja Kemah Injil Indonesia Daerah III Nabire Papua,” Jurnal J 10, no. 1 (2012): 87-109,

https://ojs.sttjaffray.ac.id/index.php/JJV71/article/view/64.

${ }^{8}$ Shintia Maria Kapojos, Randy Frank Rouw, and Hengki Wijaya, "Implikasi Kehidupan Perempuan Yahudi Bagi Gereja Masa Kini,” Evangelikal: Jurnal Teologi Injili dan Pembinaan Warga Jemaat 3 (2019): 136-143.

${ }^{9}$ Ezra Tari and Rinto Hasiholan Hutapea, "Peran Guru Dalam Pengembangan Peserta Didik Di Era Digital," Jurnal Kharisma 1, no. 1 (2020): 1-13, http://jurnalsttkharisma.ac.id/index.php/Kharis/article/view/1. 
(Fil. 4:2-9), Rasul (atau pembawa pesan Rm. 16:7). Roh Allah memberi kuasa baik kepada laki-Iaki maupun perempuan untuk bernubuat tentang karya penebusan Allah di dalam Kristus (Kis. 2:14-18 ). Partisipasi perempuan dalam penyebaran Injil secara lebih baik dan doa dalam jemaat merupakan bagian yang normal dari kehidupan jemaat pada jaman itu (1Kor. 11). Namun di dalam tulisan-tulisan yang lain: 1 Timotius 2:11-15 dan 1 Korintus 14:33b-36, Paulus menyatakan pandangan yang kontradiktif atau bertentangan, hal mana ia dengan tegas membedakan laki-laki dengan perempuan. Oleh sebab itu, tulisan ini hendak menelaah 1 Timotius 2:8-15, dengan tujuan untuk melihat bagaimana sebenarnya sikap Paulus terhadap kaum perempuan, apakah benar ia anti feminis atau tidak.

Untuk memudahkan penyelidikan, kajian teologis dari perikop 1 Timotius 2:8-15, menjadi dua struktur, yakni: Pertama, ayat 8-10, Paulus menginstruksikan laki-laki dan perempuan tentang doa dan beribadah. Kedua, Ayat 11-15, apakah perempuan boleh untuk berkhotbah atau mengajar dalam ibadat umum?

\section{Struktur Ayat 8-10}

Teks 1 Timotius 2:8-10, Paulus berbicara mengenai doa yang ditujukan kepada satu kelompok (jemaat), yakni laki-laki dan perempuan, juga membahas mengenai kehidupan dalam rumah tangga atau keluarga. Adapun yang menjadi penekanan Paulus pada kedua perikop ini adalah, "Segala sesuatu harus berlangsung dengan sopan dan teratur" (1 Kor. 14:4). Ketidakberaturan ini ditunjukkan oleh jemaat Efesus yang sedang dilayani oleh Timotius. Kebaktian-kebaktian umum sudah tidak lagi berjalan menurut peraturan dan tidak efektif, sebab para anggota jemaat baik laki-laki maupun perempuan, tidak menaati Firman Allah. Untuk mengantisipasi masalah tersebut, Paulus memberi beberapa nasihat kepada anggota jemaat Efesus, serta mengingatkan mereka akan tanggung jawab mereka untuk melakukan Firman Tuhan. ${ }^{10}$

Ayat 8 :"Oleh karena itu aku ingin, supaya di mana-mana orang laki-laki berdoa dengan menadahkan tangan yang suci, tanpa marah dan tanpa perselisihan." Pada ayat ini, Paulus dengan tegas menyatakan bahwa, orang laki-laki harus berdoa di dalam pertemuan jemaat setempat. Dalam jemaat mula-mula, baik laki-laki, maupun perempuan harus berdoa (1Kor. 11:4-5). Kebiasaan berdoa yang dijelaskan pada bagian ayat ini adalah menunjuk kepada kebiasaan-kebiasaan orang Yahudi ketika berdoa, yaitu menengadahkan tangannya tetapi Allah memalingkan muka-Nya dan tidak mau mendengarkan doanya karena tangan mereka penuh dengan darah (Yes 1:15). Kemungkinan besar mereka yang mengajarkan ajaran yang tidak sehat, adalah suka berdoa dengan menengadahkan tangan yang sia-sia dan hanya bersifat formalitas belaka karena tujuan mereka adalah untuk menyesatkan. Maka dari itu, Paulus menambahkan "berdoa dengan tangan yang suci." Di sini kita melihat ada hal-hal tertentu yang dituntut, yaitu kesungguh-sungguhan dalam berdoa. Frasa "tangan yang suci" 11 menunjuk kepada perbuatan yang seharusnya, yang berkenan dan menjadi berkat bagi semua orang. Nasihat ini terutama ditujukan kepada semua laki-

\footnotetext{
${ }^{10}$ Warren W. Wiersbe, Setia Di Dalam Kristus (Bandung: Kalam Hidup, 1996).

${ }^{11}$ David W. and Thomas F. Torrance Torrance, Calvin's Commetaries - The Second Epistle Of Paul The Apostel To The Corinthians And The Epistles To Timothy, Titus And Philemon (Michigan: Wm. B. Eerdmans Publishing Company, 1991), 163.
} 
laki yang menjadi pemimpin dalam jemaat pada masa itu. ${ }^{12}$ Tujuannya supaya mereka berbeda dengan cara atau kebiasaan berdoa yang kosong.

Frasa "tanpa marah dan tanpa perselisihan," dalam bahasa Yunaninya kata "perseli-

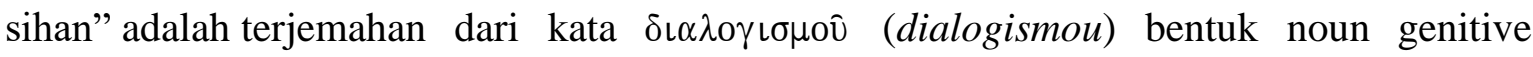

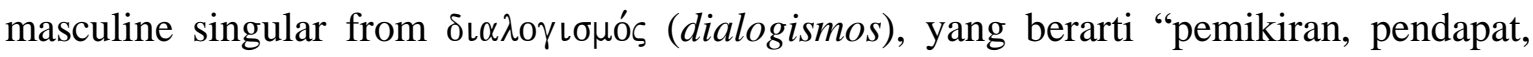
alasan, merencanakan (Band. Mrk 7:21; Luk. 2:35; 6:8; Rom. 1:21; 14:1), dan keraguan, perselisihan, pertengkaran (Band. Luk. 9:46; 24:38; Phil 2:14, dialogism, dialogue). ${ }^{13}$ Dengan demikian, berdoa yang benar, adalah memiliki hubungan yang benar dengan Tuhan (tangan yang suci), dan hubungan yang benar dengan sesama (tidak marah, tidak berselisih, tidak bertengkar).

Ayat 9-10 dimulai dengan kata $\omega \sigma \alpha u ́ \tau \omega \varsigma$ (hosautos: in like manner, likewise) "cara, gaya, sikap, kelakuan atau tatakrama," tapi juga bisa dengan "likewise" LAI: "demikian juga”. Kata "hosautos" tidak hanya menujuk pada sebuah cara dan sikap yang seharusnya bagi kaum wanita, tetapi lebih jauh lagi, yaitu menurut Paulus bahwa kedudukan perempuan dan laki-laki adalah sederajat. Hanya cara mengekpresikannya yang berbeda, yakni lakilaki melalui aktivitas (doa yang menengadahkan tangannya) dan wanita melalui penampilannya. Kesederhanan merupakan perilaku, cara atau sikap yang sangat umum pada masa itu. Oleh sebab itu, nasihat ini dilontarkan penulis surat 1 Timotius supaya jangan memakai perhiasan emas dan pakaian yang mahal. Kemungkinan ini ditujukan kepada wanita-wanita kaya yang menggunakan berbagai perhiasan dan mengenakan pakaian yang mahal-mahal, kemudian berusaha terlibat dalam kegiatan-kegiatan yang tidak bermanfaat.

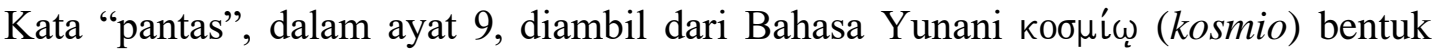

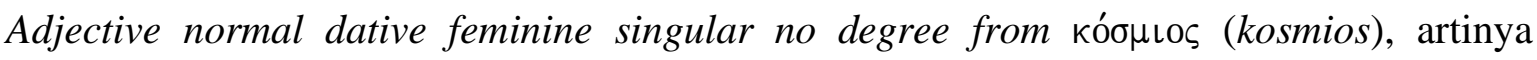
respectable (terhormat, sopan), honorable (mulia) (lih.1 Tim. 3:2), modest (lih. 1 Tit. 10). ${ }^{14}$ Kata ini berhubungan dengan kata Yunani kosmos, yang dalam Bahasa Inggris menjadi cosmos (alam semesta yang teratur), dan cosmetic (perhiasan). Dalam hal ini, pakaian perempuan haruslah yang sopan, tertib, tidak berlebihan sehingga tidak melewati batasbatas kesopanan. ${ }^{15}$ Lebih jauh lagi, Huizenga menyatakan bahwa ungkapan "sopan" itu diterjemahkan, "the women should dress themselves with modesty and sexual faithfulness." A woman's clothing, then, should reflect that modesty" (perempuan seharusnya berpakaian dengan kesederhanaan dan kesetiaan identitasnya sebagai perempuan." Pakaian perempuan, karenanya, harus mencerminkan kerendahan hati itu). ${ }^{16}$ Kata sederhana, dalam

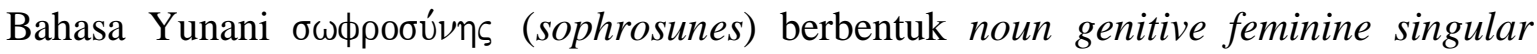

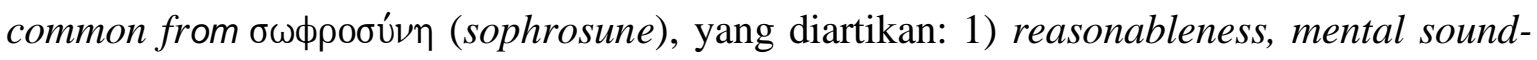
ness (Kis. 26:25) ; 2) good judgment, self-control specificallydecency, chastity (1 Tim 2:9, 35.

${ }^{12}$ Charles R. Erdman, The Pastoral Episles Of Paul (Philadelphia: The Westminster Press, 1999), 24-

${ }^{13}$ Bruce M. Metzger, A Textual Commentary On The Greek New Testament (New York: Bible Work, 2009).

${ }^{14}$ Ibid.

${ }^{15}$ Wiersbe, Setia Di Dalam Kristus, 36-37.

${ }^{16}$ Annette Bourland Huizenga, Wisdom Commentary: 1-2 Timothy Titus (Collegeville: Liturgical Press, 2016), 16. 
15), ${ }^{17}$ sehingga sederhana dalam bagian ini adalah mempunyai pikiran yang bijaksana, tenang, pengendalian diri dan cita rasa yang baik. Paulus tidak melarang perempuan menggunakan busana yang indah, perhiasan-perhiasan yang mahal, tetapi ia mengontraskan betapa murahnya pakaian-pakaian dan perhiasan yang mahal itu dibandingkan dengan nilai-nilai yang benar dari watak yang baik dan pelayanan Kristen. Kata "ibadah" merupakan kata kunci lain dalam surat-surat pastoral (1 Tim. 2:2, 10; 3:16; 4:7-8; 6:3, 5-6, 11; 2 Tim. 3:5; Tit. 1:1). Daya Tarik dapat diterapkan sebagian pada hal-hal yang lahiriah, tetapi harus berasal dari dalam (batiniah), "berdandan dengan perbuatan baik, seperti layaknya perempuan yang beribadah” (2:10).

\section{Struktur Ayat 11-12}

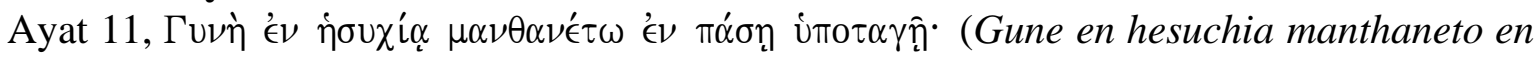
pase hupotage; Let a woman learn, In quietness in all submission). Biarkan seorang perempuan belajar, dalam keteduhan dalam segala ketundukan. Preposisi yang diulang ( $\dot{\varepsilon} v)$ adalah datif sikap; menunjukkan cara di mana perempuan diizinkan untuk belajar dalam ketenangan dan ketundukan. Penulis menggunakan dua kata yang berkaitan untuk

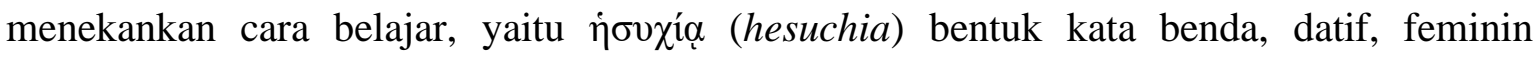
singular. Ini digunakan sebagai datif dari rasa hormat bersama dengan $\pi \alpha ́ \sigma \eta ̣ ~ v ं \pi o \tau \alpha \gamma \tilde{n}$ (pase hupotage) yang mengindikasikan keadaan di mana perempuan harus belajar; menjaga

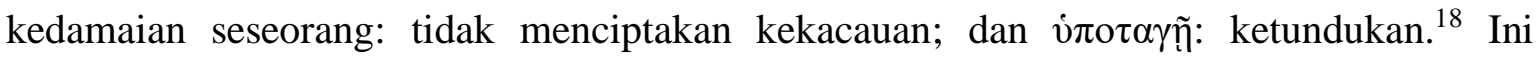
adalah sikap/tata krama di mana perempuan diizinkan untuk belajar dalam keteduhan atau keheningan dan dalam segala subordinasi. Dengan catatan, tidak menimbulkan kegaduhan dalam proses pembelajaran. ${ }^{19}$

Proses pembelajaran harus dirayakan oleh perempuan karena itu paling baik dilakukan dengan sikap kedamaian yang sesuai sepantasnya dengan kualitas secara budaya terkait dengan perempuan abad pertama (kedamaian, keteduhan, dan ketenangan). Dengan

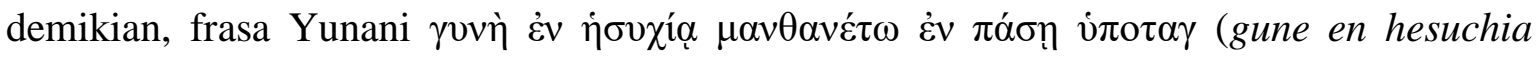
manthaneto en pase hupotage) menganjurkan agar seorang wanita harus menjadi pembelajar dalam kondisi tenang di dalam dan luar batin, menunjukkan perhatian pada ajaran yang diterima. Bagi Oden, idenya bukanlah untuk dibungkam dan tunduk tetapi untuk mencari ketenangan batin dan perhatian pada kebebasan. ${ }^{20}$ Mounce juga menjelaskan bahwa ayat 11a adalah poin utama dan diulangi dalam ayat 12c, sebagai penekanan. Dia berpendapat bahwa ayat ini menekankan sikap wanita. Berbeda dengan segmen Yudaisme yang melarang perempuan untuk belajar, Paulus menegaskan kemampuan dan nilai-nilai pendidikan perempuan. Oleh karena itu, seluruh gagasan ayat 11 tidak menyinggung gagasan bahwa perempuan seharusnya tidak belajar tetapi bagaimana mereka harus belajar. ${ }^{21}$

\footnotetext{
${ }^{17}$ Metzger, A Textual Commentary On The Greek New Testament, 196.

${ }^{18}$ F.W. Danker, The Concise Greek-English Lexicon of the New Testament (Chicago: University of Chicago Press, 2009), 366.

${ }^{19}$ Teresa Chateia David, Women, Teaching and Leadership in 1 Timothy 2:11-15: A Rhetoricalcritical Study, with Reference to Angola (Stellenbosch: Faculty of Theology at Stellenbosch University, 2009), 13.

${ }^{20}$ Oden T.C, First and Second Timothy and Titus (Louisville: Westeminster John Knox, 1989), 96.

${ }^{21}$ W.D. and Metzger Mounce, Word Biblical Commentary: Pastoral Epistles (Waco: Word Books, 2000), 19.
} 
Dengan demikian, izin untuk belajar dalam ayat tersebut akan menunjukkan bahwa Paulus tidak mendorong keheningan fisik tetapi roh yang dapat diajar. Juga, tidak ditentukan kepada siapa perempuan harus patuh. Tetapi para ahli menduga bahwa itu mungkin merujuk pada para pemimpin jemaat yang bertanggung jawab untuk mengajarkan doktrin kepada orang percaya. ${ }^{22}$ Demikian pula, Mouton menganggap gagasan "Biarkan perempuan belajar" menjadi gerakan besar dari dalam konteks budaya Yudaisme yang patriakal di mana laki-laki adalah orator, penceramah bebas dalam setiap pertemuan, namun dalam ayat ini perempuan dijinkan untuk belajar dan menafsirkan Taurat. ${ }^{23}$

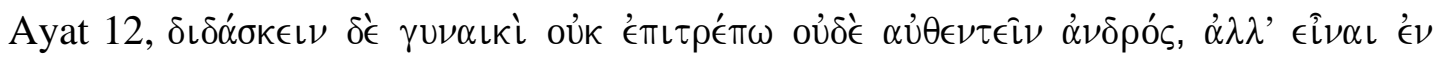
$\grave{\eta} \sigma u \chi i \underset{1}{\alpha}$ (didaskein de gunaiki ouk epitrepo oide aothentein Andros, all el nai en hesuchia).

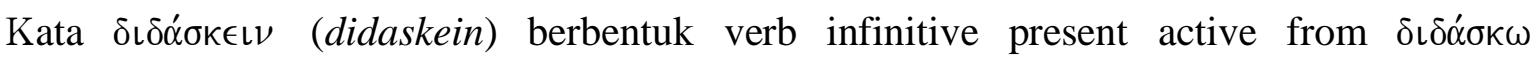
(didasko). Kata $\delta ı \delta ́ \sigma \kappa \omega ~(d i d a s k o)$ adalah tindakan memberikan instruksi kepada seseorang tentang apa yang harus dilakukan; untuk memberikan instruksi dalam pengaturan

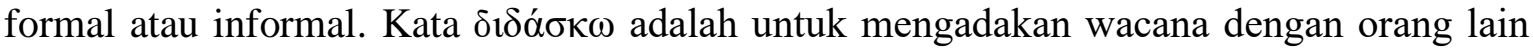
untuk mengajar mereka, menjadi guru, untuk melepaskan jabatan seorang guru, untuk memberikan instruksi, menanamkan doktrin kepada seseorang. Dua masalah tata bahasa dalam ayat ini telah menjadi pusat perdebatan dalam teologi tentang apakah Paulus melarang seorang perempuan untuk memimpin atau untuk mengajar. Menurut Kroeger, arti $\delta 1 \delta \alpha ́ \sigma \varkappa \omega$ dan $\delta 1 \delta \alpha ́ \sigma \varkappa a \lambda o \varsigma$ (didaskolos) biasanya merujuk pada isi pesan, apakah ortodoks atau heterodoks. Terhadap latar belakang ini, pencegahan berlaku lebih pada pesan daripada pada tindakan mengajar. Kroeger berpendapat bahwa $\delta l \delta \alpha ́ \sigma \varkappa \omega$ melarang pengajaran yang salah, sementara $\alpha \dot{\theta} \theta \varepsilon v \tau \varepsilon v o$ (aothenteno) menunjukkan tindakan ritual dan ideologi doktrinal yang dipromosikan oleh guru sesat yang mewakili masalah besar bagi penulis pastoral. ${ }^{24}$

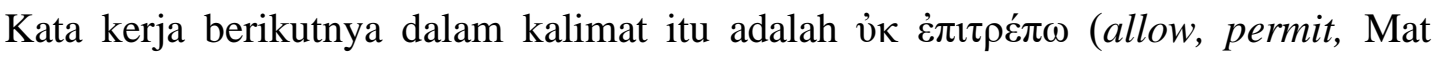
8:21; Mrk 10:4; Luk 9:59, 61; Kis. 27:3; 1 Tit. 2:12; give permission: Mrk 5:13; J 19:38; 1 Kor 16:7; Ibr. 6:3). ${ }^{25}$ Mounce berpendapat bahwa jika kekuatan semantik dari kata itu berwibawa, penggunaan indikatif tidak mengurangi kekuatannya. Dengan demikian, imperatif dalam ayat 11 telah membentuk nada bagian ini. Oleh karena itu, pergeseran dari

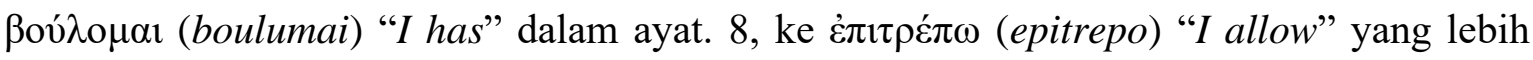
kuat menandai rasa otoritas yang semakin kuat. Karena aspek dari kata kerja ini, Mounce mengemukakan bahwa kata itu harus diterjemahkan sebagai "Saya saat ini tidak mengizinkan seorang wanita untuk mengajar atau saya tidak mengizinkan." Dengan demikian menunjukkan bahwa, pada waktu itu, Paulus ingin menahan para perempuan di Efesus untuk mengajar para pria sampai mereka sendiri diajar dengan baik. Kemudian dia lebih suka menunjukkan bahwa "Saya tidak mengizinkan" mewujudkan perintah wajib rasul untuk semua gereja. ${ }^{26}$

\footnotetext{
${ }^{22}$ Lea T.D. \& Griffin, 1, 2 Timothy, Titus (Nashville: Broadman, 1992), 98.

${ }^{23}$ E. Mouton, Reading Pastoral 'Text of Terror' in Africa Today? 1 Timothy 2:8-15 as a Context Specific Appreciation of the Creation Story (Stellenbosch: African Sun Media, 2012), 121.

${ }^{24}$ C.C. Kroeger, 1 Timothy 2:12-A Classist's View. In. Mickelsen, A. Women, and Authority \& the Bible (Downers Grove: Inter Varsity, 1986), 225.

${ }^{25}$ Metzger, A Textual Commentary On The Greek New Testament, 76.

${ }^{26}$ Mounce, Word Biblical Commentary: Pastoral Epistles, 122.
} 
Menurut Scholer, pernyataan dalam ayat 11-12 merupakan instruksi sementara yang diimpikan bagi situasi di Efesus secara khusus, yaitu pengajaran yang salah tercurah pada perempuan. Ini menjadikan instruksi-instruksi ini bukan prinsip-prinsip universal yang ditetapkan dalam "pedoman tata tertib gereja" suprasituasi yang melarang perempuan dalam pelayanan di segala waktu dan ruang. Perintah-perintah itu difokuskan pada perempuan yang, setelah dipengaruhi oleh ajaran-ajaran palsu, menyalahgunakan kesempatan normal yang dimiliki perempuan di dalam gereja untuk mengajar dan menjalankan wewenang. ${ }^{27}$

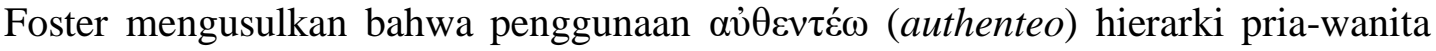
bukanlah masalahnya. Sebaliknya, Paulus membahas masalah perempuan yang telah mendukung bidat dengan mengajar mereka untuk tidak mengajarkannya kepada laki-laki. 'A $\lambda \lambda \alpha$ (all) yang merugikan (tetapi), diikuti oleh perintah untuk mengambil jovxía (keheningan) menunjukkan bahwa tindakan perempuan yang mengajar dan merampas otoritas menyebabkan gangguan, dan dengan mengikuti instruksi ini, perdamaian akan dipulihkan. Oleh karena itu, ayat 11 berkaitan dengan bagaimana para perempuan itu sendiri akan dikoreksi, sedangkan instruksi dalam ayat 12 dirancang untuk membatasi aktivitas mereka dalam menyebarkan dan mempertahankan ajaran sesat, sehingga menyebabkan kekacauan (disruption). ${ }^{28}$ Dengan demikian, Paulus mengingatkan perempuan di jemaat Efesus agar menjaga diri dan pengajaran yang baik sehingga terhindar dari perselisihan dan kekacauan dalam jemaat.

\section{Refleksi Teks 1 Timotius 2:8-12}

Berdasarkan kajian teks struktur ayat 8-10 dan struktur ayat 11-12 di atas, mengungkapkan bahwa kedudukan perempuan dan laki-laki adalah sederajat. Hanya cara mengekpresikannya yang berbeda, yakni laki-laki melalui aktivitas (doa yang menengadahkan tangannya) dan wanita melalui penampilannya. Perempuan seharusnya berpakaian dengan kesederhanaan dan kesetiaan identitasnya sebagai perempuan, serta mencerminkan kerendahan hati. Kemudian Paulus juga mengingatkan perempuan di jemaat Efesus agar menjaga sikap dan pengajaran yang baik dan tidak menyebabkan kekacauan dalam jemaat.

Refleksi teks 1 Timotius 2:8-12 di atas ingin menegaskan bahwa peran perempuan dalam pelayanan dalam jemaat memiliki porsi yang sama dengan laki-laki. Pada masa kini, Maksimilianus menjelaskan bahwa kesadaran umat diharapkan berkembang sikapnya untuk menerima dan menghargai kehadiran perempuan dan laki-laki di wilayah liturgis. Gereja hendaknya memilih pelayan-pelayannya bukan berdasarkan gender. Melainkan, berdasarkan talenta, karisma, kemampuan untuk mewartakan Injil dengan baik kepada siapapun yang paling membutuhkan pewartaan itu. ${ }^{29}$ Sebagai komunitas yang menghayati hidup dalam kesetaaan, Gereja memiliki wibawa untuk memperjuangkan kesetaraan dan keadilan dalam masyarakat.

Peran perempuan dalam pelayanan jemaat memiliki kewajiban yang sama dengan laki-laki. Elim menegaskan bahwa Alkitab tidak pernah meniadakan perbedaan antara pria

${ }^{27}$ DM. Scholer, 1 Timothy 2:9-15 \& the Place of Women in the Church (Downers Grove: InterVarsity Press, 1986), 203.

${ }^{28}$ Foster T. D., 1 Timothy 2: 8-15 and Gender Wars at Ephesus (New York: Priscilla Papers, 2016), 6.

${ }^{29}$ Maksimilianus Jemali, "Upaya Pastoral Untuk Meningkatkan Peran Kaum,” Jurnal Pendidikan dan Kebudayaan 10, no. 2 (2018): 204-218, http://unikastpaulus.ac.id/jurnal/index.php/jpkm/article/view/171. 
dan perempuan. Mereka sama dalam beberapa hal, tetapi mereka juga berbeda dalam banyak hal yang lain. Dalam kedaulatan-Nya yang mutlak, Allah telah menetapkan lakilaki di atas perempuan dalam hal otoritas, terutama dalam gereja dan rumah tangga. ${ }^{30}$ Gagasan ini juga didukung oleh Nunuk. Ia menjelaskan bahwa perempuan dan laki-laki dengan nilai yang sama dengan Allah. Yesus Kristus datang dan mati untuk melayani dan menyelamatkan perempuan maupun laki-laki. Dengan demikian, peran perempuan dalam pelayanan di jemaat diharapkan dapat maksimal dan menjadi bagian dalam kesuksesan pelayanan dalam jemaat.

\section{KESIMPULAN}

Berdasarkan pembahasan di atas, penulis dapat menyimpulkan bahwa apa yang ada dalam pemahaman atau pikiran Paulus dalam teks 1 Timotius 2:8-12, bukanlah untuk memandang kedudukan perempuan lebih rendah dari laki-laki, melainkan untuk melawan ajaran sesat yang menyusup dalam jemaat Kristen saat itu. Ajaran sesat tersebut seperti: pertama, dongeng dan silsilah yang tiada putus-putusnya (1:3-4). Kedua, ajarannya menyimpang dari kasih, hati nurani yang murni dan iman yang tulus ikhlas (1:5). Ketiga, pengajaran hukum Taurat yang tanpa pengertian dan disalahpahami oleh orang-orang Yahudi (1:6-7), serta larangan terhadap perkawinan (3:14-4:10).

Selanjutnya, untuk memahami teks 1 Timotius 2:8-12, tidak dapat dilepaskan dari konteksnya. Karena jika teks itu dipahami terpisahkan dan terlepas dari konteksnya maka yang ada hanyalah kekeliruan dan kesalahan yang dapat menimpulkan jurang antara kaum laki-laki dan perempuan, seperti yang dipahami oleh gereja-gereja yang menganggap rendah kaum perempuan. Jika gereja sudah demikian, maka ia tidak ada bedanya dengan pemahaman orang-orang Yahudi saat itu, yaitu wanita harus tunduk terhadap laki-laki, penurut, tidak memerintah, berdiam diri dan menerima ajaran dengan patuh sesuai dengan hukum Taurat. Atau sama dengan pemahaman orang Yunani saat itu, yang memandang, bahwa wanita terhormat harus hidup membatasi diri, dan bahkan tinggal di tempat yang tidak seorang pun bisa datang, kecuali suaminya. Padahal itulah ajaran yang ditantang oleh Paulus. Di samping itu, surat ini juga ditulis untuk menghindari tuduhan-tuduhan yang tidak benar terhadap orang-orang Kristen saat itu, yakni tuduhan bahwa kekeristenan melindungi dan menampung perempuan-perempuan nakal.

Kedudukan perempuan dalam Alkitab jelas bahwa Allah tidak membedakan manusia antara laki-laki dan perempuan, keduanya diciptakan oleh Allah dalam keadaan sama derajat, sejajar, dan sama nilai di hadapan Allah. Tidak ada yang lebih penting dan kurang penting, tidak ada istilah yang satu lebih tinggi daripada yang lain. Penebusan Yesus Kristus telah meniadakan segala perbedaan tersebut dan membuka jalan masuk yang sama bagi semuanya. Sehingga semua penindasan, kekerasan, dan sikap merendahkan perempuan harus dihentikan serta melihat rencana Allah bagi manusia untuk kemuliaan-Nya.

${ }^{30}$ Elim Simamora, "Peranan Perempuan Dalam Gereja : Eksposisi 1 Korintus 14 : 34," Kerugma: Jurnal Teologi dan Pendidikan Kristen 1, no. 2 (2019): 75-89. 


\section{REFERENSI}

Danker, F.W. The Concise Greek-English Lexicon of the New Testament. Chicago: University of Chicago Press, 2009.

David, Teresa Chateia. Women, Teaching and Leadership in 1 Timothy 2:11-15: A Rhetoricalcritical Study, with Reference to Angola. Stellenbosch: Faculty of Theology at Stellenbosch University, 2009.

Foster T. D. 1 Timothy 2: 8-15 and Gender Wars at Ephesus. New York: Priscilla Papers, 2016.

Erdman, Charles R. The Pastoral Episles Of Paul. Philadelphia: The Westminster Press, 1999.

Fuchs, Esther. Sexual Politics in the Biblical Narrative: Reading the Hebrew Bible as a Woman. London: Sheffield Academic Press, 2000.

Geras, Frans. "Peranan Perempuan Dalam Mengembangkan Pelayanan Di Gereja Kemah Injil Indonesia Daerah III Nabire Papua.” Jurnal J 10, no. 1 (2012): 87-109. https://ojs.sttjaffray.ac.id/index.php/JJV71/article/view/64.

Huizenga, Annette Bourland. Wisdom Commentary: 1-2 Timothy Titus. Collegeville: Liturgical Press, 2016.

Jemali, Maksimilianus. "UPAYA PASTORAL UNTUK MENINGKATKAN PERAN KAUM.” Jurnal Pendidikan dan Kebudayaan 10, no. 2 (2018): 204-218. http://unikastpaulus.ac.id/jurnal/index.php/jpkm/article/view/171.

Kapojos, Shintia Maria, Randy Frank Rouw, and Hengki Wijaya. "Implikasi Kehidupan Perempuan Yahudi Bagi Gereja Masa Kini." Evangelikal: Jurnal Teologi Injili dan Pembinaan Warga Jemaat 3 (2019): 136-143.

Kroeger, C.C. 1 Timothy 2:12- A Classist's View. In. Mickelsen, A. Women, and Authority \& the Bible. Downers Grove: Inter Varsity, 1986.

Lea, T.D. \& Griffin, H.P. 1, 2 Timothy, Titus. Nashville: Broadman, 1992.

Lisa Isherwood, IISA; Elizabeth Stuart. Introductions in Feminist Theology: Introducing Body Theology. England: Sheffield Academic Press, 1998.

Metzger, Bruce M. A Textual Commentary On The Greek New Testament. New York: Bible Work, 2009.

Mounce, W.D. and Metzger. Word Biblical Commentary: Pastoral Epistles. Waco: Word Books, 2000.

Mouton, E. Reading Pastoral 'Text of Terror' in Africa Today? 1 Timothy 2:8-15 as a Context Specific Appreciation of the Creation Story. Stellenbosch: African Sun Media, 2012.

Rafika, Yuli Nur. Kepemimpinan Perempuan Dalam Gereja Menurut Gereja Huria Kristen Batak Protestan (HKBP) Kotabaru Yogyakarta. Yogyakarta: UIN SUNAN KALIJAGA, 2018.

Scholer, DM. 1 Timothy 2:9-15 \& the Place of Women in the Church. Downers Grove: InterVarsity Press, 1986.

Setyawan, A. Teologi Seksual. Yogyakarta: Kanisius, 2014.

Simamora, Elim. "Peranan Perempuan Dalam Gereja : Eksposisi 1 Korintus 14 : 34." Kerugma: Jurnal Teologi dan Pendidikan Kristen 1, no. 2 (2019): 75-89.

T.C, Oden. First and Second Timothy and Titus. Louisville: Westeminster John Knox, 1989.

Tari, Ezra, and Rinto Hasiholan Hutapea. "Peran Guru Dalam Pengembangan Peserta Didik Di Era Digital." Jurnal Kharisma 1, no. 1 (2020): 1-13. http://jurnalsttkharisma.ac.id/index.php/Kharis/article/view/1. 
Torrance, David W.; Thomas F. Torrance. Calvin's Commetaries - The Second Epistle Of Paul The Apostel To The Corinthians And The Epistles To Timothy, Titus And Philemon. Michigan: Wm. B. Eerdmans Publishing Company, 1991.

Wiersbe, Warren W. Setia Di Dalam Kristus. Bandung: Kalam Hidup, 1996. 